\title{
Pastoral Care at the Time of Lockdown: An Exploratory Study of the Catholic Church in South Tyrol (Italy)
}

\author{
Giulia Isetti \\ Center for Advanced Studies, Eurac Research, Viale Druso 1, \\ 3910 o Bolzano (BZ), Italy \\ giulia.isetti@eurac.edu \\ Elzbieta Agnieszka Stawinoga \\ Head Office, Eurac Research, Viale Druso 1, 39100 Bolzano (BZ), Italy \\ Agnieszka.Stawinoga@eurac.edu \\ Harald Pechlaner \\ Center for Advanced Studies, Eurac Research, Viale Druso 1, \\ 3910 o Bolzano (BZ), Italy \\ Chair of Tourism/Center for Entrepreneurship, Catholic University of \\ Eichstätt-Ingolstadt, Pater-Philipp-Jeningen-Platz 2, 85072 Eichstätt, \\ Germany \\ harald.pechlaner@eurac.edu, harald.pechlaner@ku.de
}

\begin{abstract}
In order to assess the impact of COVID-19 on catholic pastoral care, an exploratory study was conducted in South Tyrol (Italy) by administering an online survey to parish priests and laypeople with an office within the local Diocese. With reference to the lockdown period, the research aimed to investigate: (1) how pastoral care was delivered; (2) changes in the use of ICT within religious activities; and (3) the vision of the future for the Church in a mediatized world. Respondents believe that: (1) pastoral activities have slowed down, even though contact with the faithful was kept up through phone or the Internet; (2) the level of digitalization of the parishes has increased; however, the communication was mostly one-way and top-down. Finally, results show that (3) attitudes towards digital media are divergent: they are perceived
\end{abstract}


as having the potential to either strengthen or weaken the relationship between the Church and the faithful.

\section{Keywords}

Catholic Church - parish priests - South Tyrol (Italy) - pastoral care - use of ICT COVID-19- lockdown

\section{Introduction}

In the early months of 2O2O, the spread and severity of the SARS-CoV-2 infection has led many countries around the globe to implement lockdowns and social distancing measures to contain the COVID-19 pandemic. Many, struggling with the immediate fear of illness and death as well as the social, psychological, political, and economic consequences of the pandemic, turned towards their faith to look for solace and reassurance. However, gatherings and pilgrimages were cited as hotbeds of transmission, as was the case among followers of the Christian worship of the Shincheonji Church of Jesus and Sarang Jeil Church, in South Korea, to which almost thousands of infections were traced (BBC, 2020, August 17). Therefore, Orthodox, Catholic, and Jewish Easter celebrations have been held behind closed doors, as has Ramadan. Since many traditional religious practices and services were discouraged, as they could have contributed to the spread of the virus, religious institutions and leaders all over the world have been forced to find new and creative ways to help people cope with the situation while maintaining religious observance and social ties within the community. This has translated, for example, into "balcony" minyans and drive-by confessionals (O'Neill, 202O) and, in most cases, in transferring online religious content and services, such as online chavruta video conferencing, shabbat streaming, and broadcasting the Passover ceremony within the Jewish context (Frei-Landau, 2020; Lieber, 2020), while Muslim believers could break fast during Ramadan within virtual iftars (Ebrahimji, 202O). Hindu believers have been relying on apps, such as vR Devotee, to be able to watch multiple holy sites and extensive footage of Hindu festivals and to experience virtual reality temples (Newens, 2020). In the Catholic context, Pope Francis, for the first time ever, livestreamed his Easter Sunday mass from a deserted St. Peter's Square, making visible "what Roman Catholic ecclesiology has long foregrounded, namely the trans-local, more-than-congregational, global, and 
indeed catholic (in the sense of 'universal') character of this church" (Berger, 2020, p. 16).

Religion has been interacting with the Internet almost since the beginning. However, the intensification of the extent to which religion has been relying on ICT during the pandemic is unprecedented, to the point that, according to the Pew Research Center (2020; Cooperman, 2020), 40\% of regular U.S. worshippers have replaced church attendance with online services instead, and one-third of U.S. adults watched religious services online or on television in July 2020.

Against this backdrop, Heidi Campbell (2020b) has recently forged the expression of "Distanced Church" to indicate:

Church where members are physically separated from one another due to specific health concerns and safety regulations. Yet the church is still called to be a social institution, where people engage, support, and care for one another. The concept of The Distanced Church suggests church leaders need to find alternatives to physical gatherings and spaces, and are engaging technological options to do this [...]. The Distanced Church is one where people are physical separated from one another but still spiritually interconnected and in need of some modified forms of technologically facilitated social interaction. (p. 4)

\section{The Catholic Church and the Internet}

For almost three decades, scholars have been investigating how ICT influences the way people practice religion, with a major focus on faithful communities and their interaction between online and offline. The body of literature on religious communities in digital religion studies may be divided into four stages: a descriptive one, in which scholars mainly focused on the (self-)description of religious communities online; a second stage with a strong focus on categorization and shared characteristics of religious communities; a third stage in which scholars highlighted the strategies applied by religious communities with regard to new technologies and platforms; and a fourth and current stage, in which scholars emphasize the intersection between online and offline practices and discourses (Campbell \& Vitullo, 2016). Hutchings (2015), for instance, highlights the two-directional relationship between digital media and religious groups: on the one hand, religious groups shape media technology in the sense that they play an active role in evaluating and designing technology, while on the other hand, and vice versa, groups are shaped by digital media and their 
own logics and norms. In a similar vein, Spadaro (2014) argues that the Internet may be regarded not merely as an external tool for communication but also as an integral part of the everyday experiences of many people. It constitutes a "cultural environment" (p. 3) that deeply shapes the ways in which people think, express themselves, and believe.

A growing interest has been devoted also to the institutional aspect, especially in contexts as centralized and structured as the Catholic Church. The more recent area of studies of digital ecclesiology, to which a special issue of Ecclesial Practices was recently dedicated, calls in fact for greater exploration of the ways "churches, church institutions, and Christian communities engage with and respond to digital media and digital cultures" (Campbell, 2020a, pp. $5^{-6) \text {. }}$

Within this context, the aim of this explorative study is to contribute to this discussion by investigating - on the basis of the case study of South Tyrol (Iт) - how pastoral care and activities were performed in early 2020 during the lockdown period imposed to contain the covid-19 pandemic, and what experiences were made in the Roman Catholic context, by analyzing a single Diocese, thanks to the intensified use of ICT.

The Catholic Church is very much aware of the potential of the Internet, to the point that Pope Francis (2014) declared it - with some caveats - a "gift of God", and Carlo Acutis, a teenager who helped run websites for Catholic organizations and who has already been dubbed "the patron saint of the Internet", was recently beatified (B BC, 2020, October 12). Moreover, Pope Francis' attention to and usage of digital media technologies and social media, such as Instagram and Twitter, have led some scholars to label his leadership a "digital papacy" (Campbell \& Vitullo, 2019) and to analyze the purpose of his social media presence and the interaction between him and his followers (Narbona, 2016).

Such awareness is not recent, however, as it dates back to the very beginnings of the Internet (see Zsupan-Jerome, 2014, for a detailed excursus on the Church's practice of social communication): the Vatican was in fact one of the first religious institutions to ensure an online presence by launching its own webpage, vatican.va, in 1995 (Campbell, 2010, p. 36). However, clear guidelines were needed, and in 2002 the Pontifical Council for Social Communications published two important documents: The Church and the Internet (2002a) and Ethics in Internet (2002b). While the latter discusses the ethical dimensions of Internet use and stresses the fact that the Catholic Church "should have a visible, active presence on the Internet and be a partner in the public dialogue about its development", the first considers the Internet's implications for the Catholic Church. The Internet is here described as relevant for many Church 
activities, including some forms of pastoral counseling and spiritual direction. With these documents, the Church explicitly invites its ministers to creatively make use of the possibilities offered by the Internet to achieve the Church's aims. However, recommendations are one thing; implementation is another.

For example, an analysis of vatican.va shows that it "falls short of the ideals it set out in its documents on the media", mostly because of a lack of emphasis on the role of the laity and because it remains a one-way communication tool, with a focus on sharing and providing information, rather than receiving and exchanging it (Lynch, 2018, pp. 41-42). Other official webpages may offer more opportunities for users' interaction and the birth of online communities; however, this is mostly left to the initiative of the single Dioceses or parish priests. Whether the needs of the faithful are met by the communication tools put in place by the Catholic Church is disputable: the increasing number and popularity of unofficial websites, forums, and apps where people meet and chat about religious topics seems to indicate otherwise (Lynch, 2018, pp. 42-43).

The interaction between Church officials and ICT has been studied under different lenses. In 2005, a study conducted by Cantoni and Zyga (2007) surveyed 5,812 Catholic religious congregations and institutes around the world, with the aim of providing an overview of their use of the Internet. A few years later, the research project PICTURE (Priests' ICт Use in Their Religious Experience) surveyed 4,992 e-Priests to find out the use they make of the web during their activities (Cantoni et al., 2012). Results showed that the clergy was increasingly using ICT for prayer, preaching, and spiritual direction. Furthermore, the higher the use of ICT, the more positive their perception was.

More recently, a survey was conducted among Croatian priests to investigate the role of ICT in the information-seeking needs and behavior of priests in their pastoral activities (Lacović \& Faletar Tanacković, 2018; Lacović et al., 2018). Although results showed a relative low familiarity with ICT, computers and the Internet were used by priests in their liturgy and caregiving role, especially by younger and well-educated respondents managing larger parishes. Older users and parish priests also use the Internet as a tool for religious activities. The Catholic Church was indeed able to re-institutionalize by making use of the Internet and reinforcing the parish in the new digital environment (Marchetti, 2015).

A recent qualitative analysis (Radde-Antweiler \& Grünenthal, 2020) about media practices of, and within, the Roman Catholic Church in Germany concluded that priests seem to have a low level of mediatization, while members of the official lay committee have a higher degree of mediatization, although restricted to selected situations and contexts. 
Finally, Marzano (2020) conducted ethnographic research that allowed him to cluster three general attitudes characterizing the Catholic response to the quarantine: the interruption of all activities (suspension), the online transposition of the traditional liturgical activities (reproduction), and the creation of new rituals (replacement).

\section{Case Study}

The present study aims to shed more light on the impact of CoviD-19 on the role of ICT on the pastoral activities of both parish priests and laypeople officially representing the faithful. In particular, by analyzing a single case study in South Tyrol (Italy), the authors seek to address three main research questions:

a) What kind of pastoral care have faithful been receiving during the pandemic?

b) How do parish priests and laypeople with an office within the Catholic Church engage with digital media within their pastoral activities? Were there any changes in the use of ICT during the first months of the covid-19 pandemic and the lockdown period?

c) What vision does the Catholic Church have for its own future in a mediatized world?

In order to provide answers to these questions, an explorative study has been conducted in South Tyrol, Italy. On the one hand, Italy was the Western country first and hardest hit by the pandemic and has therefore probably suffered from the strongest sense of existential insecurity because of an unknown virus (Molteni et al., 2020). On the other hand, Italy is also among the most religious countries in Europe - measured through religious service attendance, prayer frequency, belief in God, and self-described importance of religion in one's life - and, in the Western part of the continent, the country with the highest church attendance (Evans \& Baronavski, 2018; Pew Research Center, 2018). In this context, South Tyrol, an autonomous alpine region in the northern part of the country with approximately 527,750 inhabitants, relishes in a considerable level of self-government, mostly to protect German and Ladin speakers, which constitute linguistic minorities in Italy, and the majority of the population at regional level (69.41\% speak German and 4.53\% Ladin; ASTAT, 2011). Of the Italian regions, South Tyrol is among the most digitized, with $77.4 \%$ of households having a fixed and/or mobile broadband connection, against the national average of $74.7 \%$ (ASTAT, 2O2Ob), which might ensure greater ease of digital access to religious services for both ministers and faithful. During a survey regarding the habits of families conducted in South Tyrol in 2016 involving 
2,095 interviewees (ASTAT, 2016), almost three-quarters (73.9\%) of those interviewed called themselves religious, even if religious practice, at least as far as church attendance is concerned, is much less widespread: only $25.4 \%$ go to church regularly, $32.3 \%$ occasionally, $34.5 \%$ only on certain occasions, and $7.8 \%$ never. Statistical data concerning the religious habits of the local population during and after the lockdown period are currently scarce. Alfano et al. (2020) tried to measure the impact of CoviD-19 on extrinsic religiosity by comparing the number of searches on Google of the terms messa streaming (Italian for "streaming mass") during the lockdown, with the most recent pre-pandemic data on regional religious attendance. Results showed that religiosity has increased almost everywhere in the country, but more markedly in Central and Northern Italy - where the pandemic hit the hardest - including in South Tyrol. However, according to Molteni et al. (2020), the religious revival due to the crisis is expected to have a negligible impact on the overall longterm trend of religious change and will be likely absorbed with the reduction of individuals' existential insecurity.

Finally, South Tyroleans have declared that during the lockdown their level of trust in institutions has declined, especially in political institutions and the media, but also, albeit to a lesser extent, in religious institutions (ASTAT, 2020a).

The administrative territory of South Tyrol corresponds with that of the Catholic Diocese of Bolzano-Bressanone, which counts 281 parishes. Each parish is supported by a priest and by an officially recognized council that elects a president representing laypeople in the Diocese. As some of the parishes are relatively small in terms of faithful (the smallest counts only 70 parishioners; Italia in dettaglio, 2020), it is not rare that one priest is responsible for more than one parish. This is also caused by the well-known problem of the vocation's crisis, as the number of working parish priests has been decreasing over the years: in Italy in less than 20 years (from 1999 to 2018), the number has declined from 36,503 to 30,985 (ICSC, 2020). It is also worth mentioning that all faith- and value-based communities have been called to action to face the COVID-19 challenge (PAS, 2020), which might have put clergymen at risk of infection and even death, as a recent mortality surge for priests in Italy suggests: by April 2021, because of COVID-19, at least 269 priests had died in Italy, 28 of them in the region of Trentino-South Tyrol (Benotti, 2021).

Even if the region, due to its unique characteristics, cannot be considered representative of the national territory, South Tyrol is nevertheless an interesting laboratory in which to investigate the impact of COVID-19 on local pastoral activities and on how priests and laypeople representing the parishes interact with ICT. 


\section{Data and Methods}

\section{Survey Design and Participants}

In order to answer our research questions, a mixed-method research design was adopted. In particular, a survey was designed with the aim of investigating what kind of digital experiences parish priests and parish council presidents of the local Diocese of Bolzano-Bressanone had during their pastoral activities in the first months of the global pandemic. Moreover, major socio-demographic characteristics of individuals (role, gender, age range, education, municipality size where the (main) parish is located) were investigated, as well as the frequency with which respondents access the internet.

The online questionnaire, designed with Opinio, ${ }^{1}$ included 36 questions, consisting of a mix of open questions, Likert scales, and single and multiple choice. In the latter case, respondents had also the possibility to give their own answers if none of the options matched their experiences and attitude(s). The survey could be filled in either in German or in Italian, the two main languages spoken within the region.

At the end of the survey, participants could leave their contact details to perform follow-up qualitative telephone interviews. The twofold aim of this additional study, which will be discussed in more detail in a future publication, was to give more depth to the quantitative data collected and to monitor the development of the situation in the months following the most acute phase of the pandemic.

Participants, aged 18 or over, were reached through an email invitation sent out by the local Diocese of Bolzano-Bressanone to a target group consisting of 441 potential participants:

- 281 presidents and 15 vice-presidents of parish councils, officially representing the laypeople in the parish

- 145 parish priests/administrators

Hereinafter the two samples will be referred to as "presidents" and "priests".

Data collection lasted less than a month (from April 23, 2020 to May 18, 2020), which partly overlapped with the national lockdown period (from March 29 to May 18, 2020), and shortly after Easter (April 12, 2020). As Easter is one of the most significant periods in Christianity, the research aimed to collect feedback about respondents' religious online experience within this particular timeframe.

1 https://survey.opinio.net/. 


\section{Variables and Methods}

Data analysis was carried out using s PSs version 25. o statistical software (2007). Absolute and relative frequencies were calculated to explore how various characteristics and aspects distributed among the respondents. Additionally, for variables expressed in ordinal scale, we investigated central tendency and dispersion of the data by calculating median, mean, and standard deviation. The independent Chi-squared test was used to assess the existence of associations between two qualitative variables (e.g., to determine whether there is a relation between respondents' "age" and their "attitude towards social media use").

To support the aim of this study, we focused on a set of questions related to: (a) pastoral care provided to the faithful during the lockdown; (b) use of ICT before and after the pandemic and self-evaluation of ICT affinity; and (c) outlook.

The first aspect (a) was measured through three questions expressed in a 5-point Likert scale. The first question measured the degree of agreement with statements relating to "community and people". The other two measured the frequency of occurrence with regard to several aspects of "supporting sick or dying people" and "performing funerals" during the pandemic.

In order to measure the use of ICT (b), four questions were used: two multiple choice questions investigated what kind of digital content respondents were offering within their pastoral activities before and after the outbreak of the pandemic, and what digital platforms were being used. Moreover, respondents were asked to list the most used websites to perform their role. The last question, expressed in a 5-point Likert scale, measured the degree of agreement with nine statements aimed at evaluating ICT affinity. A factorial technique such as Principal Component Analysis (PCA) was conducted to identify latent dimensions existing among the items related to the self-evaluation of ICT affinity. The factors with eigenvalue higher than 1 were chosen and major loadings of each item to selected factors were considered to obtain the final solution. Subsequently, the median values of the respective items were calculated to operationalize the created components.

Two questions were chosen to investigate the vision respondents had for the future (c). The first asked respondents whether they would continue to offer digital content within their pastoral activities once the limitations to contain the spread of the coronavirus have lapsed, while the second question asked respondents how they believed that the relationship between Church institutions and the faithful would change in the future. The responses were: "It will be weakened" (-1), "It will remain the same" (o), "It will be strengthened" (1), "I don't know" (2). As an open field allowed for respondents to motivate their answers, these were analyzed with the software GABEK-WinRelan 
(Holistic Processing of Linguistic Complexity), a computer-assisted method in qualitative research and textual analysis that allows for the reduction of complexity by coding texts on a keyword basis. The output consists in a visual overview (association graph) of the respondents' statements as semantic networks. Generally, the graphs show the link between keywords that are mentioned at least once by respondents within the same conceptual unit (Zelger, 2000).

The frequency of respondents' Internet access was measured by the question "How often do you access the Internet (via smartphone, tablet and/or computer)?" with four modalities of response: "Several times a day", "Several times a week", "Several times a month", "A few times a year". According to the frequency distribution, respondents were categorized as either habitual (accessing the Internet several times a day) or occasional users (accessing the Internet from a few times a year to several times a week).

Non-parametric tests, such as the Mann Whitney U test or Krustal-Wallis test, were employed to determine the existence of statistically significant differences between two or more groups of an independent variable, identified on the bases of their socio-demographic characteristics, on a continuous or ordinal dependent variable (i.e. dependent variable would be "attitudes towards social media use", measured on a 5-point scale from "strongly agree" to "strongly disagree", and independent variable would be "age"). For all statistics tests, the significance level was set at 0.05 .

\section{Results}

\section{Sample Description}

A total of 164 participants completed the survey in full for a total response rate of $37.6 \%$. Response rate was higher among the presidents $(39.2 \%$, with 116 complete surveys) than among the priests (33.1\%, with 48 complete surveys). Since the questionnaire was distributed online, the sample might suffer from under-coverage (Bethlehem, 2010), as only respondents that accessed the Internet during the data collection period of time could have completed the survey. The representativeness of the target population of South Tyrolean presidents and priests was, however, evaluated by examining the language of completion: the proportion of surveys filled in in German (82.9\%) and in Italian $(17.1 \%)$ is consistent with the linguistic affiliation of German (85\%) and Italian $(15 \%)$ speaking parishes in South Tyrol (Diocese of Bolzano-Bressanone). The language of completion was not taken into consideration in later analyses.

The largest number of respondents is from the $\geq 61$ age group (43.5\%). Parish priests raise the average age of respondents; in fact, $53.2 \%$ of them belong to 
this age range. The average age of diocesan and parish priests in South Tyrol is 77 years (Diocese of Bolzano-Bressanone).

Regarding educational level, a large majority of respondents indicated that they held secondary education ( $52.5 \%)$, followed by graduate and postgraduate $(38.3 \%)$, while only a few (9.3) had primary education. Priests are mostly graduate and postgraduate $(76.6 \%)$, as they are expected to have higher educational level because of their role, while presidents have mostly a secondary education $(66.1 \%)$.

Respondents' parishes are mostly situated in municipalities with more than 3,001 inhabitants (43.5\%), and between 1,001 and 3,000 (34.8\%).

Habitual Internet users make up $78.7 \%$ of respondents, while $21.3 \%$ are occasional users. Even though the percentage of habitual users increases to $81.3 \%$ if only parish priests are considered, the percentage is still considerably lower than in the priests' sample described by Cantoni et al. (2012), where $94.7 \%$ of respondents accessed the Internet daily. Table 1 reports the relative frequencies for the chosen variables.

a) Pastoral Care Provided to the Faithful during the Lockdown

As shown in Table 2, respondents agree or strongly agree with the fact that religion (90.5\%) and the Church $(84.2 \%)$ can help the faithful to deal with the crisis linked to the pandemic and that the faithful are enthusiastic about the church's digital offerings (69.8\%), even if they agree that the pastoral activities have slowed down (60.5\%). Responses are fragmented in terms of the support given to the sick; however, respondents recognize that for the faithful the thought of burial is in most cases more frightening than before.

Responses did not significantly differ according to socio-demographic data, nor according to the frequency of access to the Internet, with two exceptions. The first is linked to the respondents' role: presidents ( $\mathrm{MR}=67.46)$ agree more with the statement "People require support over the telephone more than before" than priests (53.49) $(z=2.161, p=0.031)$. It is, however, difficult to assess whether this difference can be explained by the fact that presidents are closer to their communities, as they represent them, and therefore are more aware of the actual needs of the faithful or, opposing that, they are not as aware as the priests of the actual demands.

The ethnographic research performed by Marzano (2020) highlighted three general attitudes which characterized the response of Catholics during the pandemic: reproduction, replacement, and suspension. According to his analysis, in the latter case, parish priests decided to take a break and temporarily interrupt all pastoral activities. We would like to add to this consideration that the number of parishes priests administer to might play a role in this decision. This is in fact the second factor that influences responses: priests with one or 
TABLE 1 Characteristics of survey sample $(\mathrm{N}=164)$

\section{Demographics}

Survey completion language [German]

Survey completion language [Italian]

Role [president]

Role [parish priest]

Number of parishes [1-2]

Number of parishes $[\geq 3]$

Gender [female]

Gender [male]

Gender [Prefer not to say]

Age [18-40]

Age [41-50]

Age $[51-6 \circ]$

Age $[\geq 61]$

Education [primary]

Education [secondary]

Education [graduate and postgraduate]

Municipality size where the parish is located [ $\leq 500]$

Municipality size where the parish is located [500-1,00o]

Municipality size where the parish is located $[1,001-3,000]$

Municipality size where the parish is located $[\geq 3,001]$

Internet access frequency [habitual user]

Internet access frequency [occasional user]
$\%$

82.9

17.1

70.8

29.2

42.6

$57 \cdot 4$

40.9

56.1

3.0

8.1

18.6

29.8

$43 \cdot 5$

$9 \cdot 3$

52.5

38.3

$9 \cdot 3$

12.4

34.8

43.5

78.7

21.3

two parishes (27.61) tend to agree more with the statement "For many people, religion and spirituality can help to deal with this difficult situation" than priests with three or more (19.63) $(z=-2.203, p=0.028)$. At the same time, the latter (26.94) agree more with the statement "Pastoral activity has slowed down during this period of crisis" than those with only one or two parishes (18.07) $(z=2.340, p=0.019)$. These two factors might indicate that respondents administering three or more parishes encountered more difficulties in supporting their parishioners during the pandemic and are therefore generally less optimistic that religion can be a help for the faithful.

This is also confirmed by at least six presidents working alongside priests who have to administer to other parish(es) in addition to theirs. For example, when asked within an open-ended question about their perception of the relationship between the faithful and the parish priest during the lockdown period, 


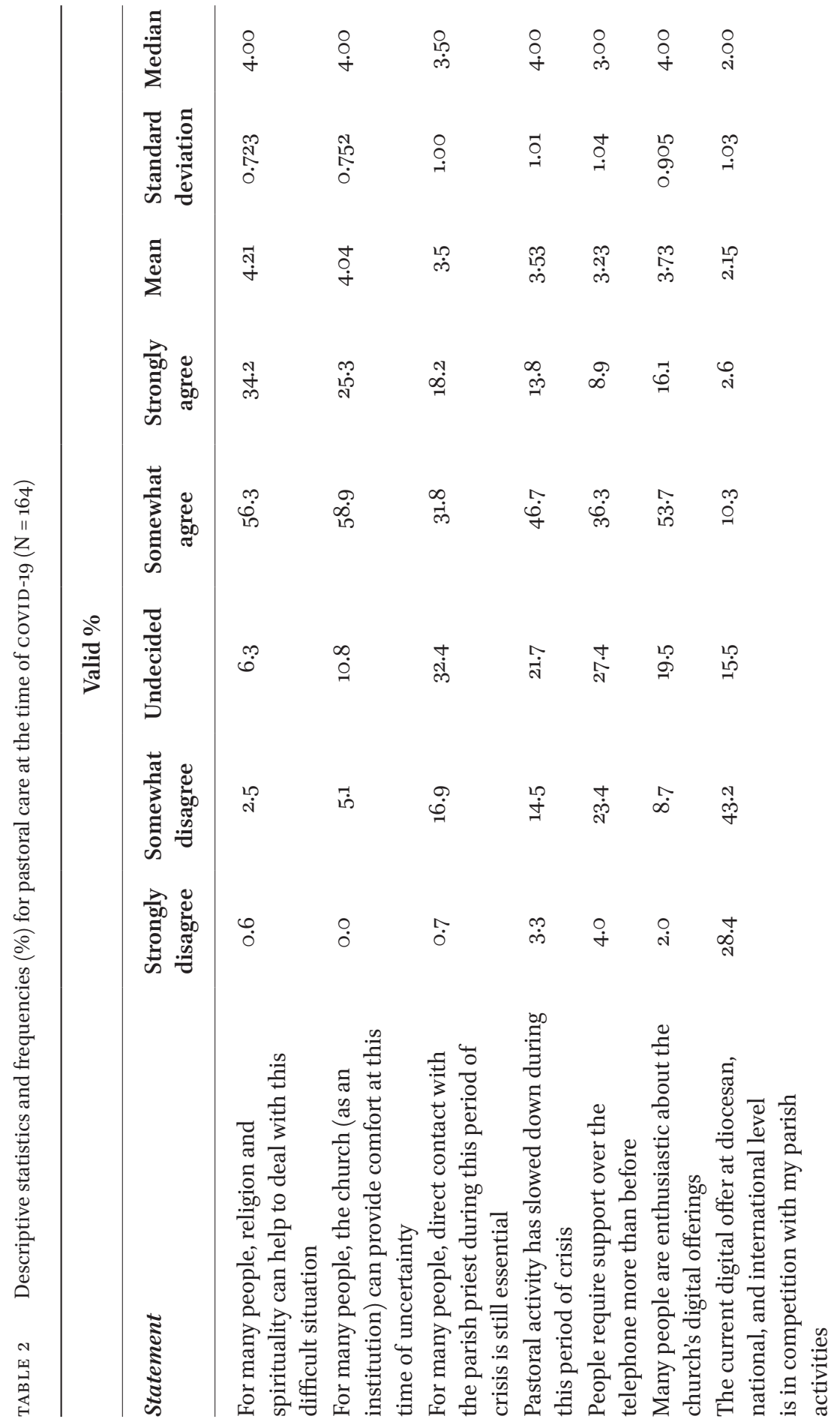




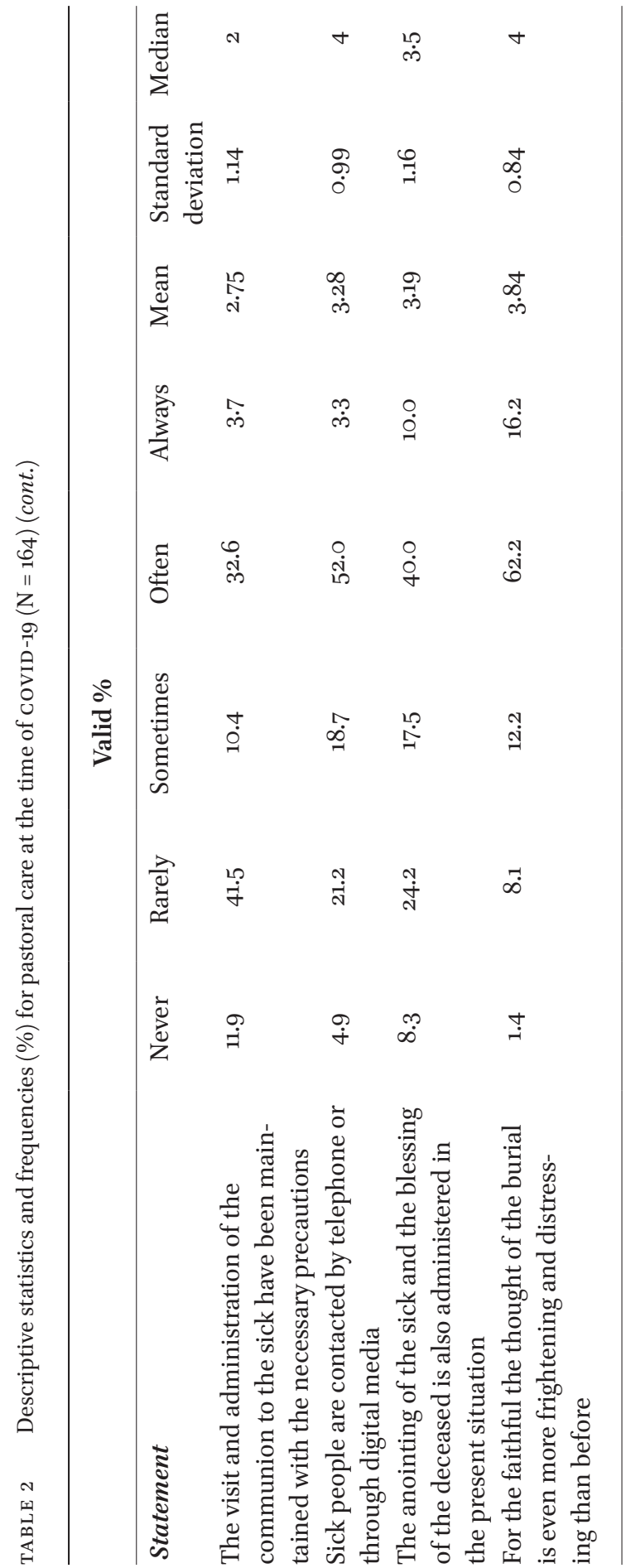


two of them stated: "In our parish nothing was shared with our priest because he has his seat in the neighbor's parish and we never saw him the whole time" (respondent 38, president), and "As the pastor is not resident in our parish, contact with him has been broken off. Only in case of urgent questions or in case of death he is 'consulted' over the telephone" (respondent 98, president).

b)

Stated Use of ICT before and after the Pandemic and SelfEvaluation of ICT Affinity

Principal Component Analysis (PCA) was conducted on the nine items measuring the degree of ICT affinity (Table 3). Four components were extracted, accounting for $72.34 \%$ of the total variability: component 1 consists of five elements and refers to self-assessment of the level of digitalization; component 2 is made up of two items regarding the use of ICT during the pandemic; component 3 , privacy issues, consists of one element, as does component 4, impact of covid-19.

The self-assessment of the level of digitalization has been tested in relation to socio-demographic information and to the frequency with which respondents access the Internet. As could be expected, habitual users of the Internet (86.89) assess themselves as more digitized than occasional users (66.33) $(z=2.67, p=0.008)$, and respondents in the age group 18-40 as more digitized (113.69) than those in the age group 41-50 (85.02), 51-6o (79.65), and 61 and above $(73.71)\left(\chi^{2}(3)=11.93, p=0.008\right)$. The pairwise comparison revealed statistically significant differences between the youngest group and the groups of $51-600=0.035)$ and 61 and above $(p=0.005)$. Educational level $\left(\chi^{2}(2)=1.646\right.$, $p=0.439)$ and role $(z=0.127, p=0.899)$ do not yield any significant impact on the self-assessment.

The fact that the Internet is considered useful or very useful for performing parish activities by the majority of respondents $(91 \%)$ is in line with results showed by Cantoni et al. (2012). On the other hand, most respondents (75.6\%) use social media to perform pastoral activities, whereas data collected in 2009-2010 (Cantoni et al., 2012) showed that social media were then deemed much less useful by most e-Priests, which might indicate a progressive openness towards these tools.

Component 2 does not yield any difference among socio-demographic groups; however, regarding the statement, "The level of digitalization of parishes has increased due to the limitations caused by the coronavirus", priests who administer to only one or two parishes are more in agreement (27.39) than those who administer three or more (19.79) $(z=-2.299, p=0.021)$, meaning that those with fewer parishes have probably been engaging more with ICT to perform their activities.

Component 3, privacy issues, is not influenced by any variable. This was investigated because strict compliance with regulations about data protection 
TABLE 3 Descriptive statistics for the single items and PCA components used to measure the degree of ICT affinity $(\mathrm{N}=164)$

Statement

Mean Standard Median PCA deviation loadings

$\begin{array}{lllll}\text { I use social media in the context of } & 3.80 & 0.860 & 4.00 & 0.800\end{array}$ my parish activities

I use social media in my private life I have the feeling that I can keep

4.10

$0.793 \quad 4.00$

0.734

up with the development of digital

3.42

1.010

4.00

0.726

technology

I consider myself skilled in the use

of ICT

The Internet is an aid to my parish activities

\begin{tabular}{llllc} 
Component 1 & $\mathbf{3 . 8 9 6}$ & $\mathbf{0 . 7 7 0}$ & $\mathbf{4 . 0 0}$ & - \\
\hline $\begin{array}{l}\text { The level of digitization of parishes } \\
\text { has increased due to the limitations }\end{array}$ & 3.84 & 0.760 & 4.00 & 0.571 \\
$\begin{array}{l}\text { caused by the coronavirus } \\
\begin{array}{l}\text { The shift of religious life to digital } \\
\text { The }\end{array}\end{array}$ & 3.39 & 0.875 & 4.00 & 0.533
\end{tabular}
channels, following the coronavirus

0.974

4.00

0.702

4.13

0.671

4.00

0.631

crisis, is working very well

Component 2

Component 3

\begin{tabular}{lllc}
3.622 & 0.709 & 4.00 & - \\
\hline 3.14 & 1.132 & 3.00 & 0.737
\end{tabular}

When I use ICT to address my worshippers, I am concerned about personal data protection

\section{Component 4}

COVID-19 has changed and will $3 \cdot 35$ 0.999 4.00 0.843 change the way we live spirituality and religion to such an extent that there is no turning back

is often an issue, especially in the German-speaking context (see also Raimann, 2020). Component 4, impact of COVID-19, was excluded in further analysis as it does not explicitly refer to the use of ICT.

Results of the stated use of Іст before and after the spread of the pandemic have been summarized in Table 4. Albeit fewer and to a lesser extent, respondents were already using ICT during their pastoral activities before the 
TABLE 4 Percent of cases (\%) for digital content offered before and after the limitations put in place to contain the pandemic $(\mathrm{N}=164$, multiple choice)

$\%$

Before After

Sharing and making available information and/or texts (produced by others) for the faithful (e.g. biblical texts, $43.2 \quad 63.6$ reading advice, and gospel for meditation) on webpages or social media (e.g. Facebook, WhatsApp, YouTube)

Radio or video streaming Sharing and making available information and/or texts

(produced by you in person) for the faithful (e.g.

biblical texts, reading advice, and gospel for meditation) on web pages or social media (e.g. Facebook, WhatsApp, YouTube)

Organisation of small virtual gatherings/meetings

(via WhatsApp/Skype/Zoom and other channels) with other parish priests/council members

Organisation of small virtual gatherings/meetings

(via WhatsApp/Skype/Zoom and other channels) with the faithful

No digital content or activity

limitations were put in place. During lockdown, the supply of digital content increased for all types; in particular, respondents have been mostly sharing and making available information and/or texts (produced by others) for the faithful on webpages or social media (64\%) and radio or video streaming (49.3\%). Small virtual gatherings and meetings, with both other parish priests or council members and the faithful, doubled (respectively 26.4 and $22.1 \%$ ). Respondents not providing any digital content decreased from $24.3 \%$ to $16.4 \%$.

None of the variables identified in Table 1 (socio-demographic factors and use of Internet) yielded an impact on the answers, with one exception: after the limitations were put in place, priests have been sharing and making available information produced by themselves $(65 \%)$ more than presidents $(38 \%)$.

At the time of the survey, among the most used platforms to carry out pastoral activities and communicate with the faithful, respondents named mostly WhatsApp $(76.2 \%)$, chat, and e-mail $(75.6 \%)$, while other platforms, such as Facebook (28.०\%), the website of their own parish (27.4\%), YouTube $(24.4 \%)$, and Zoom (13.4\%), were much less used. 

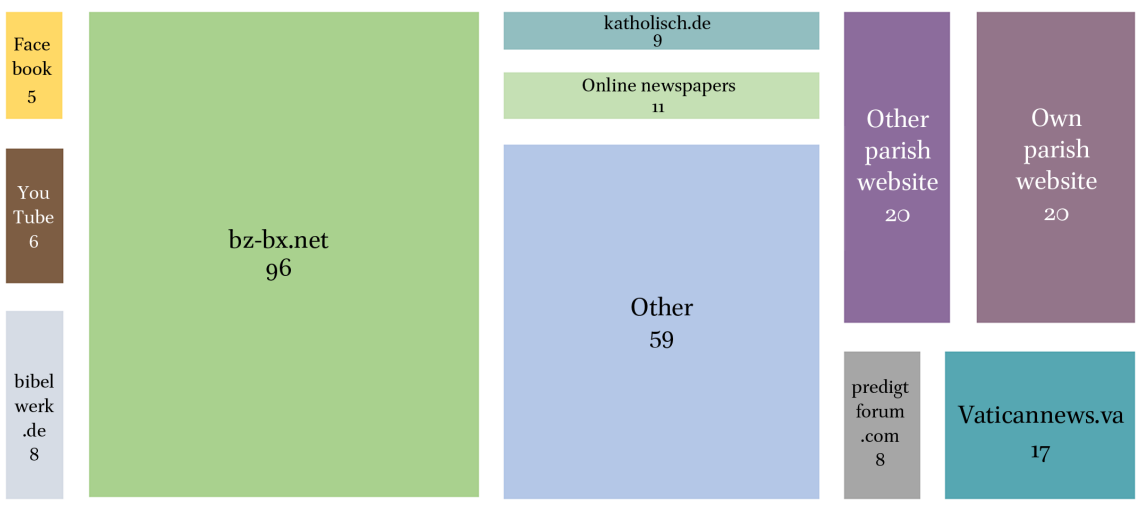

FIGURE 1 Most used websites within pastoral activities - absolute numbers $(\mathrm{N}=164)$. OWN ELABORATION

Respondents were also asked to indicate which websites they found more useful/were using more frequently as a source of information within their pastoral activities (see Fig. 1): the most mentioned was by far the website of the local Diocese of Bolzano-Bressanone (named by 96 respondents), followed by their own (28) or other parishes' websites (20). The official website of the Vatican was mentioned by only 17 respondents; other responses are fragmented. The fact that the most used websites are the local Diocese's and their own or other parishes' is consistent with previous findings applying Chatman's (1999) theory of social network to the analysis of ICT in the work of Catholic priests (Lacović et al., 2018). According to the theory, members of a group are more prone to look for and use information coming from their social group, and the Catholic Church, with its hierarchical structure, can be identified as a specific social network for information sharing among its members.

c)

\section{Outlook}

As indicated in Table 3, respondents stated a higher use of ICT after the spread of the pandemic to perform their pastoral activities; however, among the risks arising from the situation for the faithful (Table 5), "overestimation of new media" is the item named by most respondents (38.4\%).

Nevertheless, as shown in Table 6, most of the respondents state that they will continue to offer digital content once limitations will be lifted, albeit to a lesser degree; indeed, $26.8 \%$ of respondents claim they would even offer them to the same degree in the future, while $21.9 \%$ were undecided, and only $3.7 \%$ answered they would not offer digital content.

Finally, respondents were asked their view on how the relationship between Church institutions and the faithful might change in the future (Table 7). 
TABLE 5 Perception of the risks posed by the current crisis for the faithful $(\mathrm{N}=164$, multiple choice)

\begin{tabular}{|c|c|}
\hline & $\%$ \\
\hline Overestimation of new media & 38.4 \\
\hline Social distance might become even more pronounced & 36.0 \\
\hline $\begin{array}{l}\text { Distancing from the faith due to the lack of activities and services } \\
\text { traditionally offered by the parish/Church }\end{array}$ & 31.7 \\
\hline $\begin{array}{l}\text { The mass could be no longer be considered a central element of } \\
\text { the Church }\end{array}$ & 31.1 \\
\hline Mistrust of others & 18.9 \\
\hline $\begin{array}{l}\text { Disappointment in the lack of support during the crisis from } \\
\text { institutions (including the Church) }\end{array}$ & $17 \cdot 7$ \\
\hline $\begin{array}{l}\text { Offers that were appreciated during the period of restrictions will } \\
\text { be missed afterwards }\end{array}$ & 17.1 \\
\hline Lack of exchange with other faithful in the post-crisis period & 16.5 \\
\hline Loss of importance of the priest & 10.4 \\
\hline $\begin{array}{l}\text { Emergence of divisions between intra-ecclesial realities with } \\
\text { different spiritualities }\end{array}$ & 6.7 \\
\hline Other & 6.7 \\
\hline I do not know & 11.1 \\
\hline
\end{tabular}

TABLE 6 Intention to offer digital content within pastoral activities, once the limitations are lifted $(\mathrm{N}=164)$

\begin{tabular}{lr}
\hline & $\%$ \\
\hline Yes, to the same degree & 26.8 \\
Yes, to a lesser degree & 47.6 \\
No & $3 \cdot 7$ \\
Don't know/Missing & 21.9 \\
\hline
\end{tabular}

The answers were almost perfectly balanced between the four options: "It will be strengthened", "It will remain the same", "It will weaken", and "I don't know". Moreover, none of the variables identified in Table 1 yielded an impact on the type of answer. Both factors may indicate the great uncertainty perceived by respondents at the time of filling in the survey. As it was possible to motivate the responses in an open field, comments were analyzed with $\mathrm{GABEK}^{\circ}$ to produce a linguistic net with the keyword "future" as the center of the graph 
TABLE 7 Perception of how the relationship between Church institutions and the faithful will change in the future $(\mathrm{N}=164)$

$\%$

It will be strengthened 26.2

It will remain the same

22.0

It will weaken

26.2

I don't know

25.6

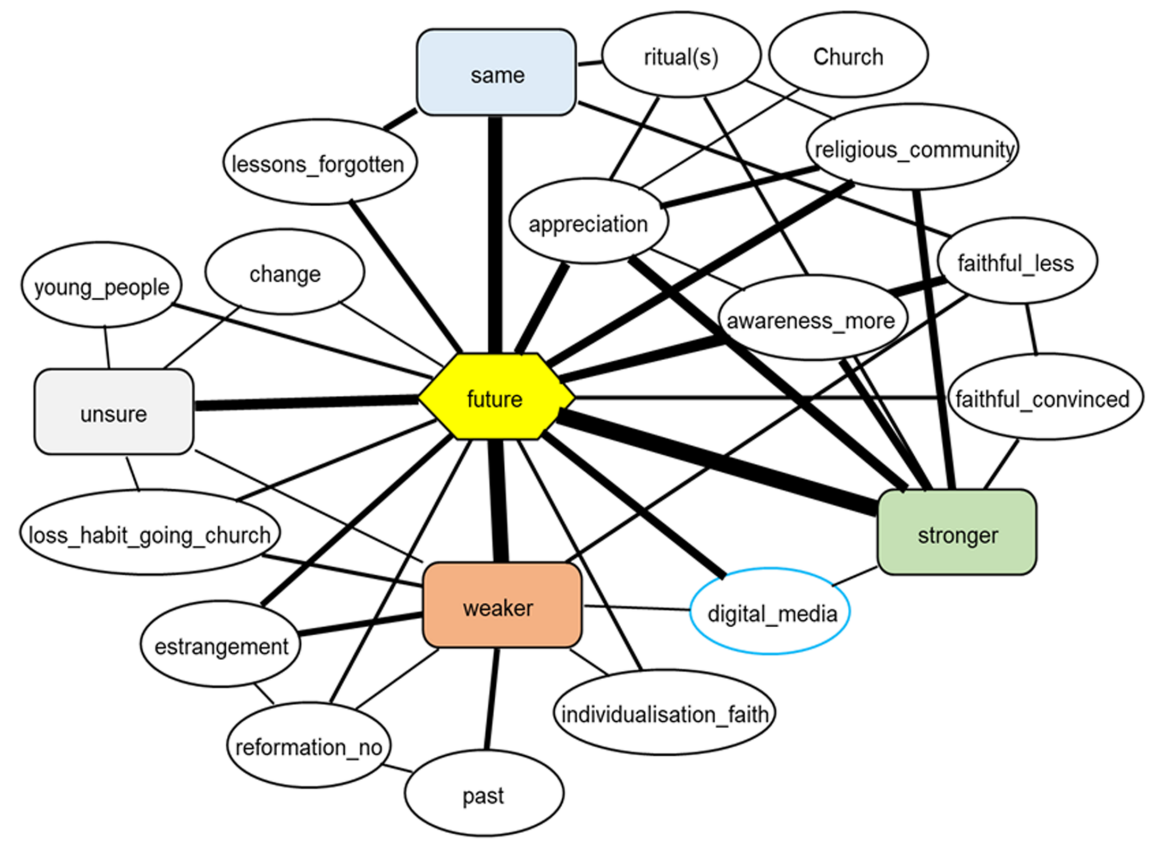

FIGURE 2 How will the relationship between Church institutions and the faithful change in the future? $(\mathrm{N}=93)$.

GABEK ASSOCIATION GRAPH

(Fig. 2). The four answer options - stronger, same, weaker, and unsure - were then expanded by a factor of two. Therefore, the linguistic net results represent keywords - symbolized by ellipses - which, if connected by a black line, appear together in at least two meaningful text units. The connecting lines' thickness in the graphs highlights the frequency of the mental connections: the thicker the lines, the more frequently a connection has been established.

Examining the figure clockwise from the top, respondents who stated the relationship between Church institutions and the faithful will not change 
("same") mostly highlight that as soon as the crisis linked to the coviD-19 pandemic is over, there will be a return to the previous status quo, as the lessons learned will be quickly forgotten. "Nowadays religious life is of interest to fewer and fewer people, the crises in which God is needed again are quickly forgotten and the usual routine continues" (respondent 6, president). In addition, those who foresee a strengthening of the relationship between the Church and the faithful in the next years ("stronger") point out that the number of faithful was already decreasing before the pandemic. According to these respondents, even if fewer, the faithful will be more committed, as the social distancing measures have made them more aware and appreciative of the importance of rituals, the religious community, and the Church in general. One respondent stated: "Perhaps the number of the faithful will decrease, but those who return to religious practice (in church) will be more motivated, more conscious" (respondent 30, president). Digital media are perceived in an ambivalent way; in fact, they are seen as a factor that can either weaken or further strengthen the Church-faithful relationship, as the following statements show: "Virtualization embrittles the interpersonal relationship" (respondent 133, priest), and "The absence of physical relationships and the efforts made to overcome it by using alternative [digital] means to offer spiritual closeness will be in favour of such a [stronger] relationship" (respondent 136, priest). Those who foresee a weakening ("weaker") identify a progressive estrangement of the faithful, already started before the crisis, also due to the fact that the Church has not been able to modernize. A respondent stated: "It will be weakened, but not only because of the CoviD-19 crisis. This process had already started [because of] its interaction with women, abuse of power, etc." (respondent 105, president). Moreover, because of social distancing measures, the faithful have either stopped attending rituals, especially the mass, or are attending only digitally. In the latter case, they have been getting used to switching on and off as they please, living their religion privately and individually, which might undermine the concept of Church and religious community. As one respondent wrote: "The believers of the future will become more independent and individual in their faith. Large church-filling communities will make way for smaller and smaller groups and family house churches" (respondent 158, priest). Some foresee a change but are not able to identify in which direction ("unsure"). According to them, a key role will be played by the younger generations and by the ability of the Church to address and involve them in the future. A respondent stated: "It depends on us how well we start. Approaching people and delegating responsibility, distributing tasks and especially addressing young people and families" (respondent 101, president). 


\section{Discussion, Conclusion, and Limitations}

As stated above, within the framework of the current project we are conducting qualitative interviews with a random sample of (1) respondents to the survey here presented and (2) parish priests within the Diocese of BolzanoBressanone that did not participate in the survey. Results of this second step of the research will be shared in a future publication.

In this first part of the study, we conducted an explorative survey aimed at parish priests and lay presidents of parish councils in South Tyrol, to address three research questions.

Regarding the first research question (a), respondents believe that religion and the Church can support the faithful during this time of crisis, as well as direct contact with the parish priests. However, respondents report that pastoral activity has slowed down, even if efforts are being made to keep contact with the faithful, e.g. through phone or digital media. Respondents perceive that even if the contact is not as intense as it used to be, the efforts put in place by the Church to provide the faithful with some pastoral care during the pandemic have been mostly appreciated by the parishioners.

Results show that there is a positive attitude towards the Internet and social media, which are deemed useful tools within pastoral activities (b). Respondents claim that they were already using ICT within their pastoral activities before the pandemic broke out, and during the lockdown the level of digitalization of the parishes has further increased. However, the efforts seem more focused on sharing and making available information, rather than establishing a two-way communication with the faithful.

Regarding the outlook (c), results show that in the future, church services might still be shaped by the lockdown experience, as the respondents seem inclined to continue offering digital content within their pastoral activities even once the social distancing measures are lifted. Respondents, however, have very different perceptions regarding the consequences of the use of digital media, and see it either as an opportunity to strengthen the relationship between church institutions and the faithful or as a factor that could further weaken it.

Contrary to the study by Cantoni and Zyga (2007), and in line with Lacović and Faletar Tanacković (2018) and Lacović et al. (2018), our results show some statistically relevant relations between socio-demographics and opinions or perceptions related to the aspects under consideration. In particular, welleducated and younger respondents, as could be expected, are more familiar with ICT. Differently from Radde-Antweiler and Grünenthal (2020), our analysis did not highlight a higher level of digitalization in lay respondents in comparison with priests. 
Priests seem to have different attitudes towards ICT according to the number of parishes they administer: those responsible for three or more seem to have decreased pastoral activities and contact with the faithful. This is a surprising result, as it might have been expected that these respondents would leverage digital media to reach parishioners that normally would have been scattered across the region and met only from time to time. A causal conclusion cannot be drawn from this; however, the result might indicate that the more parishes a priest administers to, the less he is familiar with the faithful, and the less he feels invested in contacting them and providing them with pastoral care. As the shortage of parish priests is set to further worsen in the future, priests will have to administer to more parishes. Closeness to and support of the faithful could be partly facilitated by ICT, and it therefore seems advisable for this target group to be subject to specific training courses that enable them to set up and make the best use of these tools. However, as Pillay (2020) concluded in a recent paper, "If all the church has learnt during this time of covid-19 is how to live-stream sermons, worship songs, religious rites and requests for tithes, we have lost the Kairos moment" (p. 9). The Church should in fact not only focus on transposing standard offline worship services to an online platform which Marzano (2020) calls reproduction-butalso rethink the relationship with the faithful according to their needs and transform worship services accordingly (Campbell, 2020c). The level of trust in religious institutions is already decreasing, especially after the lockdown (ASTAT, 2020a), and according to our results, both priests and presidents are well aware of the fact that the Church has reached a crossroads. The Church can either seize the Kairos and deeply modernize its structures and approaches, for example, by delegating responsibilities and activities to laypeople, including women, and encouraging also through ICT - a two-way communication with the religious community or assist in the progressive estrangement of the faithful.

As most case studies, the present work has some limitations, such as the replicability of results in other contexts and their generalizability. Moreover, retrieved data on the use of ICT rely on self-assessment by respondents rather than actual behavior and on their perception of how faithful are living these times of uncertainty, which remain both unobserved and might be subject to future research.

\section{Acknowledgements}

We extend our thanks to Michael de Rachewiltz, Claudia Marina Lanzidei, Maximilian Walder, Charlotte Hartung von Hartungen, Jessica Rosco, Michaela Fischer, and Anna Weithaler (Eurac Research) for their assistance throughout 
the project, to the Diocese of Bolzano-Bressanone, in particular Reinhard Demetz - who helped in designing and distributing the survey, to the anonymous reviewers for their valuable comments and suggestions, and to the respondents that kindly took the time to complete the survey, allowing this research to be possible. The authors thank Eurac Research for covering the Open Access publication costs.

\section{References}

Alfano, V., Ercolano, S., and Vecchione, G. (2020). Religious Attendance and covid-19: Evidences from Italian Regions. CESifo Working Paper No. 8596. https://ssrn.com/ abstract $=3707936$.

ASTAT (2011). Censimento generale della popolazione e delle abitazioni [Population and housing census]. https://astat.provincia.bz.it/it/censimento-generale-popolazioneabitazioni.asp.

ASTAT (2016). Indagine sulle famiglie. Tipi di famiglia, valori e progetti di vita degli altoatesini [Family survey. Types of family, values and life projects of South Tyrolean]. https://astat.provincia.bz.it/it/news-ubblicazioni-info.asp?news_action=4\&news_ article_id $=607477$.

ASTAT (2020a). Covid-19 lockdown. https://astat.provincia.bz.it/it/news-pubblicazioniinfo.asp?news_action=4\&news_article_id $=641710$.

ASTAT (2020b). SDG Tracker. https://astat.provinz.bz.it/barometro/upload/sdg/html/ en/detail_9.html.

В ВС (2020, August 17). South Korea church coronavirus cluster causes alarm. BBC News. https://www.bbc.com/news/world-asia-53803011.

В ВС (2020, October 12). Carlo Acutis: Italian teenager could be first millennial saint. BBC News. https://www.bbc.com/news/world-europe-54507064.

Benotti, R. (2021, April 1). I 269 preti morti di Covid in un anno [The 269 priests who died from the coronavirus in one year]. SIR [Society for Religious Information]. https:// www.agensir.it/chiesa/2021/o4/o1/i-269-preti-morti-di-covid-in-un-anno-il-virusha-azzerato-il-ricambio-generazionale/.

Berger, T. (2020). @Worship goes viral: Catholic Liturgy online in a coviD-19 World. In: H. A. Campbell, ed., Digital Ecclesiology: A Global Conversation, Digital Religion Publications, pp. 14-19.

Bethlehem, J. (2010). Selection bias in web surveys. International Statistical Review 78(2), pp. $161-188$.

Campbell, H. A. (2010). When religion meets new media. New York: Routledge.

Campbell, H. A. (2020a). Introduction: Studying Digital Ecclesiology: How Churches are Being Informed by Digital Media and Cultures. Ecclesial Practices 7(1), pp. 1-10. 
Campbell, H. A. (2020b). A Distanced Church in a Time of Pandemic... An Introduction. In: H. A. Campbell, ed., The Distanced Church: Reflections on Doing Church Online. Digital Religion Publications, pp. 3-6. http://hdl.handle.net/1969.1/187891.

Campbell, H. A. (2020c). What Religious Groups Need to Consider When Trying to Do Church Online. In: H. A. Campbell, ed., The Distanced Church: Reflections on Doing Church Online. Digital Religion Publications, pp. 49-52. http://hdl.handle. net/1969.1/187891.

Campbell, H. A., and Vitullo, A. (2016). Assessing changes in the study of religious communities in digital religion studies. Church, Communication and Culture 1(1), pp. $73^{-89}$.

Campbell, H. A., and Vitullo, A. (2019). Popes in Digital Era: Reflecting on the Rise of the Digital Papacy. Problemi dell'informazione 44(3), pp. 419-442.

Cantoni, L., Rapetti, E. G., Tardini, S., Vannini, S., Arasa, D., and Ruiz, L. (2012). Priesthood and the Internet: The International Research PICTURE. In: J. M. La Porte and B. Mastroianni, eds., Comunicazione della Chiesa: Identità e Dialogo, Rome: Edizioni Sabinae, pp. 227-246.

Cantoni, L., and Zyga, S. (2007). The use of Internet communication by Catholic congregations: a quantitative study. Journal of Media and Religion 6(4), pp. 291-309.

Chatman, E. A. (1999). A Theory of Life in the Round.Journal of the American Society for Information Science 5o(3), pp. 207-217.

Cooperman, A. (2020, August 17). Will the coronavirus permanently convert in-person worshippers to online streamers? They don't think so. Pew Research Center. https:// www.pewresearch.org/fact-tank/2020/o8/17/will-the-coronavirus-permanentlyconvert-in-person-worshippers-to-online-streamers-they-dont-think-so/.

Ebrahimji, A. (2020, April 23). How coronavirus has changed Ramadan for Muslims this year. CNN. https://edition.cnn.com/2020/04/23/us/ramadan-celebrationscoronavirus-trnd/index.html.

Evans, J., and Baronavski, C. (2018, December 5). How do European countries differ in religious commitment? Pew Research Center. https://www.pewresearch.org/ fact-tank/2018/12/05/how-do-european-countries-differ-in-religious-commitment/.

Francis (2014). Message of Pope Francis for the 48th World Communications Day; Communication at the Service of an Authentic Culture of Encounter. Vatican. https:// www.vatican.va/content/francesco/en/messages/communications/documents/ papa-francesco_20140124_messaggio-comunicazioni-sociali.html.

Frei-Landau, R. (2020). "When the Going Gets Tough, the Tough Get-Creative”: Israeli Jewish Religious Leaders Find Religiously Innovative Ways to Preserve Community Members' Sense of Belonging and Resilience During the Covid-19 Pandemic. Psychological Trauma: Theory, Research, Practice and Policy 12(1), pp. 258-26o.

Hutchings, T. (2015). Christianity and Digital Media. In: S. D. Brunn, ed., The Changing World Religion Map, Dordrecht: Springer, pp. 3811-383o. 
ICSC (2020). Rendiconti 8xmille. Rome: Istituto Centrale per il Sostentamento del Clero. http://www.icsc.it/icsc/istituto/oooooo65_rendiconti_8xmille.htm.

Italia in dettaglio (2020). Le parrocchie in Italia. http://italia.indettaglio.it/ita/ parrocchie/parrocchie.html.

Lacović, D., Badurina, B., and Džinić, I. (2018). Information and Communication Technology in the Work of Catholic Priests. Journal of Religious \& Theological Information 17(1), pp. 8-21.

Lacović, D., and Faletar Tanacković, S. (2018). Information Needs and Behavior of Catholic Priests in Croatia. Journal of Religious \& Theological Information 17(3), pp. 81-99.

Lieber, A. (2020). Networked individuals: The virtual reality of the sabbath in twentyfirst century American Judaism. In: G. Isetti, E. Innerhofer, H. Pechlaner, and M. de Rachewiltz, eds., Religion in the Age of Digitalization: From New Media to Spiritual Machines, London: Routledge, pp. 72-85.

Lynch, A. P. (2018). Global Catholicism in the twenty-first century. Singapore: Springer.

Marchetti, R. (2015). La Chiesa in internet: la sfida dei media digitali. Roma: Carocci editore.

Marzano, M. (2020). The Catholic Church and the challenge of the pandemic. Etnografia e ricerca qualitativa 2, pp. 267-277.

Molteni, F., Ladini, R., Biolcati, F., Chiesi, A.M., Dotti Sani, G.M., Guglielmi, S., Maraffi, M., Pedrazzani, A., Segatti, P., and Vezzoni, C. (2020). Searching for comfort in religion: insecurity and religious behaviour during the COVID-19 pandemic in Italy. European Societies 23(sup1), S704-S720. https://doi.org/10.108o/14616696.2020. 1836383 .

Narbona,J. (2016).Digital Leadership, Twitter and Pope Francis. Church, Communication and Culture 1(1), pp. 90-109.

Newens, C. (2020, August 25). Gods in the machine. Rest of the World. https:// restofworld.org/2020/hey-bhagwan/.

O'Neill, N. (2020, March 18). Priest offers drive-through confessional amid coronavirus outbreak.NewYorkPost.https://nypost.com/2020/o3/18/priest-offers-drive-throughconfessional-amid-coronavirus-outbreak/.

PAS (2020). Responding to the pandemic, lessons for future actions and changing priorities. Vatican City, Holy See: Pontifical Academy of Sciences and the Pontifical Academy of Social Sciences. http://www.pas.va/content/accademia/en/ events/2020/coronavirus.html.

Pew Research Center (2018, May 29). Being Christian in Western Europe. https://www. pewforum.org/2018/05/29/being-christian-in-western-europe/.

Pew Research Center (2020, August 7). Attending and watching religious services in the age of the coronavirus. https://www.pewforum.org/2020/08/o7/attending-andwatching-religious-services-in-the-age-of-the-coronavirus/. 
Pillay, J. (2020). Covid-19 Shows the Need to Make Church More Flexible. Transformation 37(4), pp. 266-275. https://doi.org/10.1177/o265378820963156.

Pontifical Council for Social Communications (2002a). The Church and Internet. Vatican.http://www.vatican.va/roman_curia/pontifical_councils/pccs/documents/ rc_pc_pccs_doc_20020228_church-internet_en.html\#_ftn21.

Pontifical Council for Social Communications(2002b). Ethics in Internet. Vatican. http:// www.vatican.va/roman_curia/pontifical_councils/pccs/documents/rc_pc_pccs_ doc_20020228_ethics-internet_en.html.

Radde-Antweiler, K., and Grünenthal, H. (2020). "New Possibilities for Carrying out their Ministry to and for the Word of God"? The Roman Catholic Church as a Religious Organisation in Times of Deep Mediatisation. Ecclesial Practices 7(1), pp. $67-82$.

Raimann, R. P. (2020). Digital is the new normal: Churches in Germany during the Corona Pandemic. In H. A. Campbell, ed., The Distanced Church: Reflections on Doing Church Online. Digital Religion Publications, pp. 31-33. http://hdl.handle. net/1969.1/187891.

Spadaro, A. (2014). Cybertheology: Thinking Christianity in the Era of the Internet. New York: Fordham University Press.

SPSS Inc. (2007). spss for Windows, Version 16.o. Chicago.

Zelger, J. (2000). Twelve Steps of GABEK WinRelan: A Procedure for Qualitative Opinion Research, Knowledge Organization and Systems Development. In: R. Buber and J. Zelger, eds., GABEK 2. Zur qualitativen Forschung [On qualitative Research], Innsbruck: Studien-Verlag, pp. 205-220.

Zsupan-Jerome, D. (2014). Connected toward communion: The church and social communication in the digital age. Collegeville, Minnesota: Liturgical Press. 